Instytut Archeologii

Uniwersytet Mikołaja Kopernika w Toruniu

ul. Szosa Bydgoska 44/48, 87-100 Toruń

redekcislo@gmail.com

Radostaw Cisto

\title{
BADANIA WERYFIKACYJNE DOMNIEMANEGO PRZEDZAMCZA ZACHODNIEGO ZAMKU KRZYŻACKIEGO W PAPOWIE BISKUPIM
}

Zarys treści. W artykule przedstawiono wstępne wyniki badań archeologicznych, które przeprowadzono w lipcu 2018 roku w obrębie pozostałości zamku w Papowie Biskupim, w ramach projektu pt. „Castra Terrae Culmensis - na rubieży chrześcijańskiego świata ${ }^{1}$ " i kierowanego przez Marcina Wiewiórę z Instytutu Archeologii Uniwersytetu Mikołaja Kopernika w Toruniu. Prace prowadzono na obszarze domniemanego przedzamcza zachodniego, którego istnienie, jak dotąd, nie zostało zweryfikowane. Badania potwierdziły występowanie śladów osadnictwa na obszarze położonym na zachód od domu konwentu zamku w Papowie, co można łączyć $\mathrm{z}$ funkcjonowaniem $\mathrm{w}$ tym miejscu drugiego przedzamcza.

Słowa kluczowe: Papowo Biskupie, zamek, przedzamcze, Krzyżacy, Castra Terrae Culmensis, ziemia chełmińska.

\section{W S T E P}

Papowo Biskupie położone jest w zachodniej części ziemi chełmińskiej, około $35 \mathrm{~km}$ na północ od Torunia (ryc. 1). Zamek znajduje się w centrum miejscowości, nieopodal kościoła oraz drogi prowadzącej z Chełmży do Chełmna. W czasach historycznych drogą u podnóża zamku biegł ważny szlak komunikacyjno-handlowy łączący Toruń z Chełmnem, a dalej z Grudziądzem i Malborkiem - stolicą państwa zakonu krzyżackiego.

\footnotetext{
${ }^{1}$ Projekt badawczy (nr 2bH 150078 83) finansowany w ramach Narodowego Programu Rozwoju Humanistyki.
} 


\section{H I S T O R I A B A D A Ń}

Pierwsze badania obiektu w Papowie przeprowadził w 1887 roku Conrad Steinbrecht podczas akcji inwentaryzacyjnej zamków krzyżackich na terenie Prus i ziemi chełmińskiej. Efektem jego prac było między innymi opracowanie planu założenia zamkowego, który obowiązywał w literaturze przedmiotu do pierwszego dziesięciolecia XXI wieku (Steinbrecht 1888, s. 20-24). W kolejnych latach warownią w Papowie Biskupim zainteresowali się także inni niemieccy badacze: Johannes Heise, Karl Heinz Clasen i Bernhard Schmidt (Heise 1889, s. 163; Clasen 1927, s. 63-65; Schmid 1939, s. 114; 1940, s. 73-74). Po drugiej wojnie światowej, w latach 1958-1959, szczegółową inwentaryzację pomiarowo-opisową obiektu wraz z analizą architektoniczną przeprowadzili Ireneusz Sławiński oraz Marian Arszyński. Wyniki ich cennych prac nie zostały jednak opublikowane i w formie maszynopisów znajdują się w archiwum Wojewódzkiego Urzędu Ochrony Zabytków w Toruniu (Arszyński 1958; Sławiński 1959). Dodatkowo o zamku w Papowie Biskupim można znaleźć wzmianki w katalogach autorstwa Bohdana Guerquin oraz Leszka Kajzera, Stanisława Kołodziejskiego i Jana Salma (Guerquin 1984, s. 249-250; Kajzer, Kołodziejski, Salm 2001, s. 369-370). Swój wkład w badania nad interesującą nas warownią miał także Waldemar Rozynkowski (Rozynkowski 1995; 2002, s. 339-352). Nie należy również zapominać o dziełach Tomasza Torbusa i Christofera Herrmanna, w których także znajdują się istotne informacje o warowni (Torbus 1998, s. 574-581; Herrmann 2007, s. 358-360).

Niewątpliwy przełom w badaniach nad zamkiem w Papowie Biskupim miał miejsce w latach 2005-2008, kiedy przeprowadzono pierwsze prace archeologiczno-architektoniczne, którymi kierował Marcin Wiewióra z Instytutu Archeologii Uniwersytetu Mikołaja Kopernika w Toruniu. Po kilkuletniej przerwie, w 2012 roku, zespół toruńskich archeologów zdecydował się kontynuować badania, wówczas kierowali nimi Bogusz Wasik i Agata Momot. Pozyskano wiele nowych informacji odnośnie wyglądu i rozplanowania papowskiej warowni, które przyczyniły się do weryfikacji planów założenia autorstwa C. Steinbrechta. Dodatkowo na kanwie wspomnianych badań powstało kilka publikacji, które w znacznym stopniu uzupełniły dotychczasową wiedzę o zamku (ryc. 2) (Wiewióra 2007, s. 29-305; 2013, s. 181-200; Momot i in. 2014, s. 65-98; Momot, Wasik 2015, s. 317-329; Wasik 2015, s. 83-101; 2016).

\section{H I S T O R I A Z A M K U}

Najstarsza wzmianka o Papowie Biskupim pochodzi z tzw. dokumentu łowickiego wystawionego 5 sierpnia 1222 roku. Na jego mocy miejscowość stała 


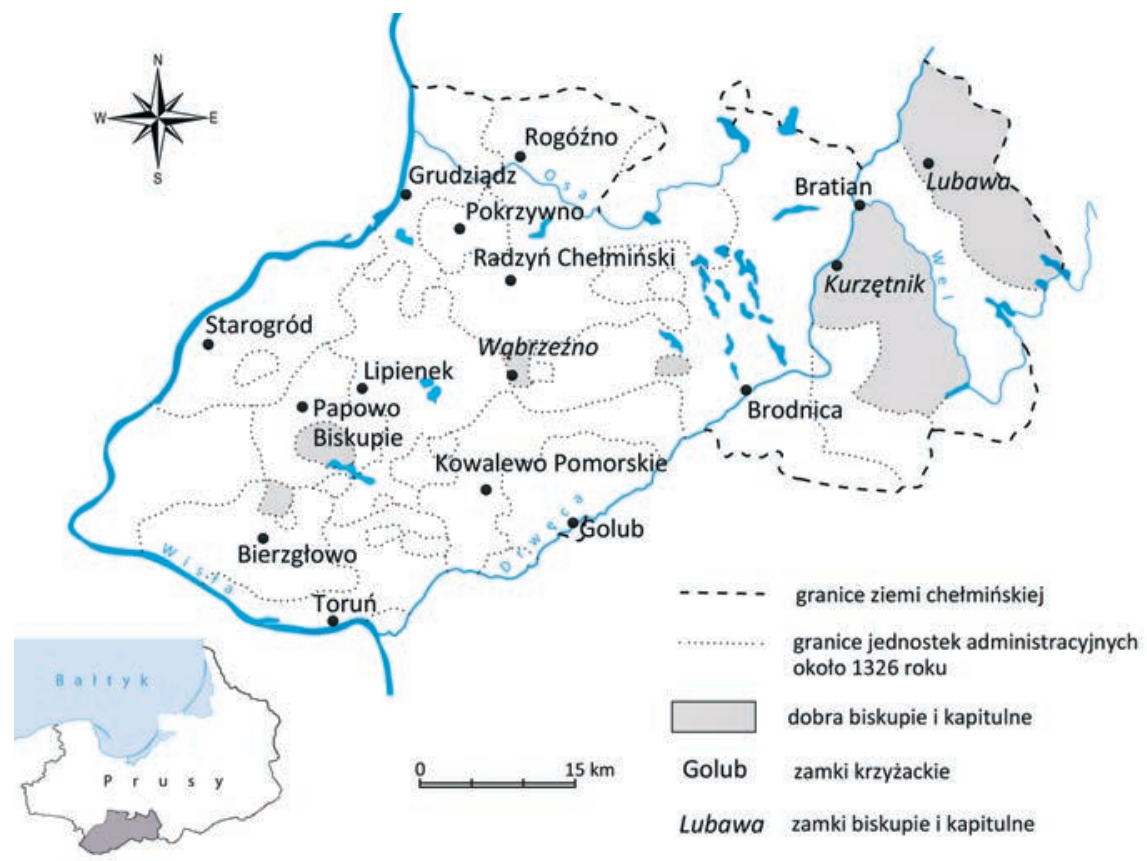

Ryc. 1. Ziemia chełmińska w XIV wieku (oprac. B. Wasik)

Fig. 1. Chełmno Land in the $14^{\text {th }}$ century (edited by B. Wasik)

się własnością biskupa Chrystiana (Rozynkowski 1995, s. 8). Na przełomie lat 70. i 80. XIII wieku zakon krzyżacki utworzył w Papowie komturię, a jej pierwszym zwierzchnikiem znanym ze źródeł pisanych był Aleksander (Jóźwiak 1997, s. 130-132; Wasik 2015, s. 85). Prawdopodobnie równocześnie z powołaniem tej jednostki administracyjnej przystąpiono do wznoszenia murowanego założenia, należącego do jednego z pierwszych regularnych zamków konwentualnym na ziemi chełmińskiej (Torbus 1998, s. 126-127). Zdaniem Bogusza Wasika dotychczasowe ustalenia dotyczące chronologii jego budowy wydają się słuszne. Początek inwestycji można zatem datować na lata 80 . XIII wieku, jednakże prace budowlane prowadzone były również w pierwszej ćwierci XIV wieku (ryc. 3) (Torbus 1998, s. 127; Wasik 2015, s. 86).

W skład założenia zamkowego, wzniesionego na pagórku między jeziorami, wchodził dom konwentu oraz rozległe przedzamcze okalające go od strony północnej i wschodniej. Elementem, który wyróżnia warownię w Papowie spośród innych zamków ziemi chełmińskiej jest budulec. Dom konwentu w przeważającej części wzniesiono z kamieni w technice opus emplectum (Wasik 2015, s. 86).

W XIV wieku Papowo odgrywało ważną rolę administracyjną i gospodarczą w strukturach państwa zakonnego. Kolejne stulecie nie było jednak dla miejscowości łaskawe i wskutek wojen polsko-krzyżackich górujący nad okolicą zamek zaczął stopniowo podupadać. Na mocy drugiego pokoju toruńskiego warownia 


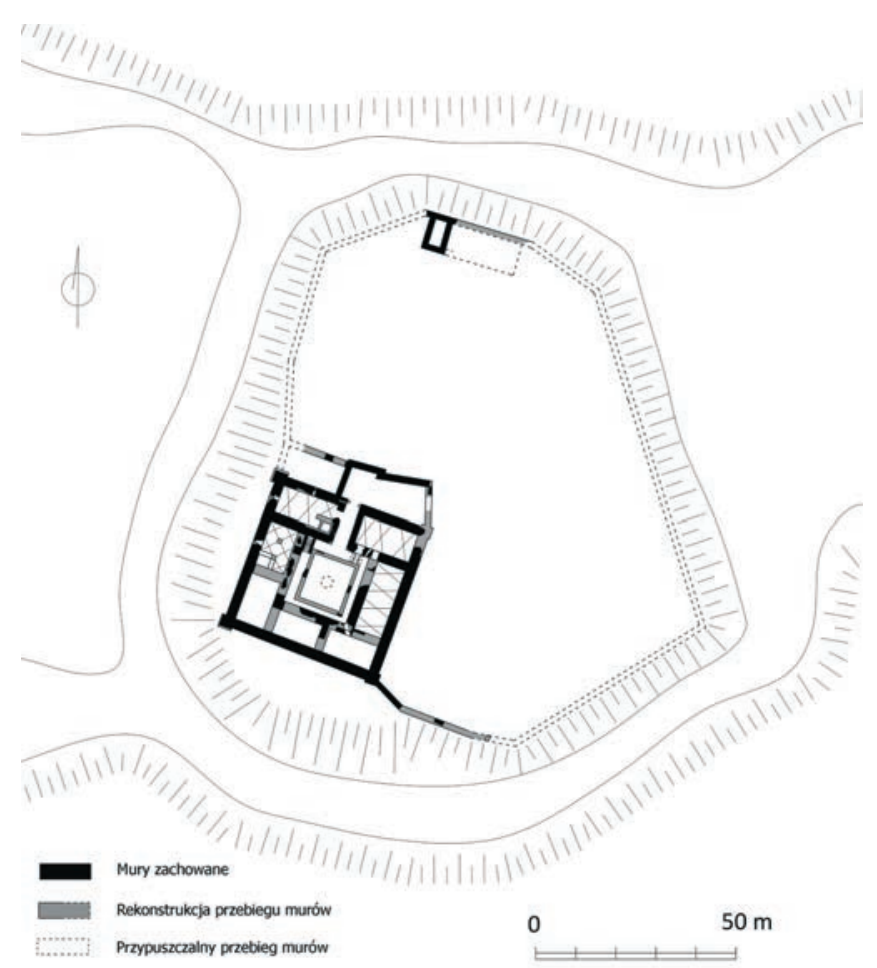

Ryc. 2. Papowo Biskupie, pow. Chełmno. Rzut założenia zamkowego na podstawie aktualnych wyników badań (oprac. B. Wasik)

Fig. 2. Papowo Biskupie, Chełmno district. Plan of the castle based on the current research results (edited by B. Wasik)

wraz ze wszystkimi dobrami weszła w skład Królestwa Polskiego. Pierwszym starostą papowskim został Gabriel Bażyński, który pełnił ten urząd w latach 1458-1474. W 1505 roku król Aleksander Jagiellończyk przekazał zamek biskupowi chełmińskiemu Mikołajowi Chrapickiemu i od tego momentu obiekt stracił jakiekolwiek znaczenie militarne. Dodatkowo rozpoczęła się jego powolna destrukcja, zaczęto też rozbierać mury zewnętrzne. Akcja rozbiórkowa, zakończona w 1639 roku, związana była z potrzebą pozyskania materiału do budowy seminarium diecezjalnego w Chełmnie. Prawdopodobnie właśnie wtedy do poziomu przyziemia rozebrano skrzydło południowe. Inwentarze z XVII i XVIII wieku wskazują, że w tym czasie dom konwentu był już niezamieszkaną ruiną, a na przedzamczu wznosiły się budynki gospodarcze. Po pierwszym rozbiorze Polski w 1772 roku Papowo Biskupie znalazło się w granicach Prus. Procesu zniszczenia zamku dopełnili lokalni mieszkańcy, którzy wykorzystywali go jako darmowe źródło budulca. W ten sposób rozebrano całkowicie mury przedzamcza wschodniego wraz z zabudową gospodarczą oraz wewnętrzne mury zamku wysokiego do poziomu przyziemia (Rozynkowski 2002, s. 339-352). 


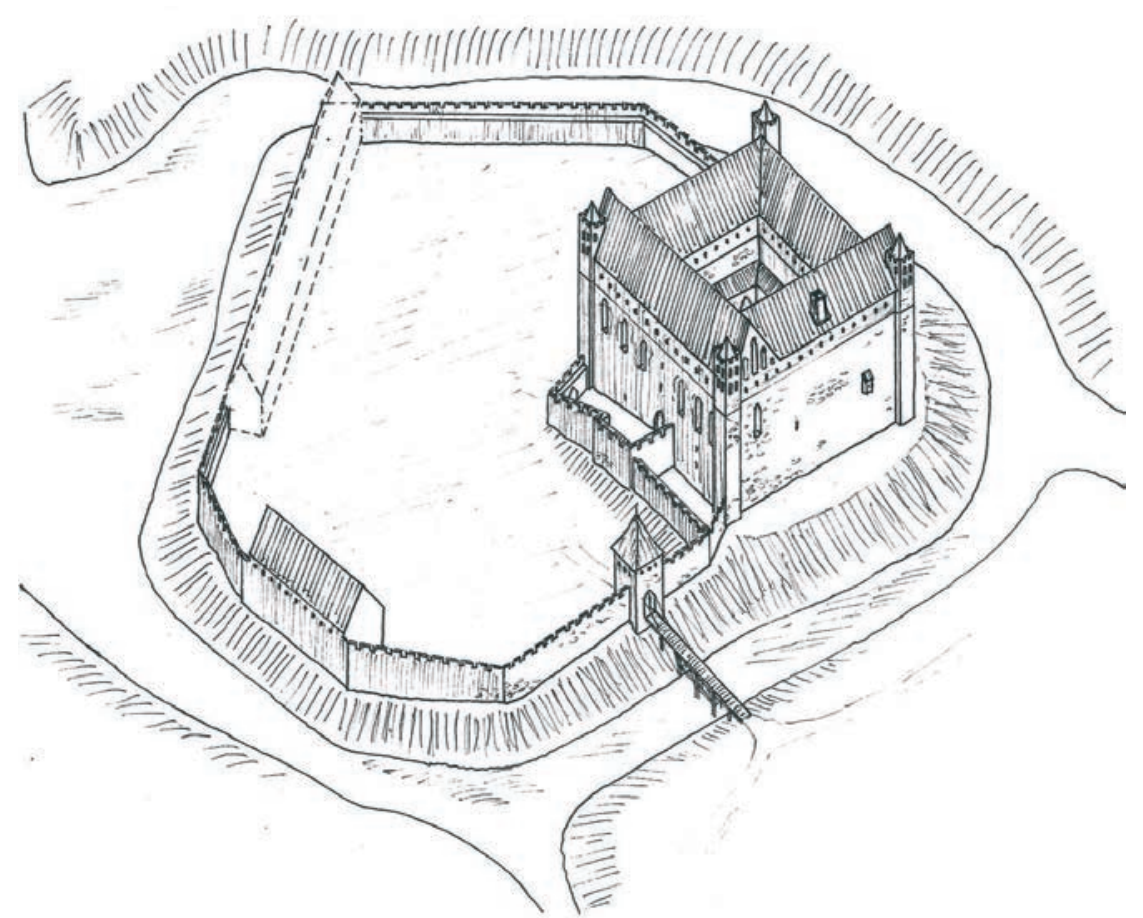

Ryc. 3. Papowo Biskupie, pow. Chełmno. Rekonstrukcja założenia zamkowego (oprac. B. Wasik)

Fig. 3. Papowo Biskupie, Chełmno district. Reconstruction of the castle layout (edited by B. Wasik)

\section{B A D A N I W E R Y F IKA C Y J N E}

Kolejne badania archeologiczne na zamku w Papowie Biskupim miały miejsce w lipcu 2018 roku. Obiekt ten został wytypowany do przeprowadzenia badań w ramach projektu „Castra Terrae Culmensis - na rubieży chrześcijańskiego świata"2, kierowanego przez Marcina Wiewiórę z Instytutu Archeologii UMK w Toruniu. Tym razem obiektem badań nie był dom konwentu, ani przedzamcze wschodnie, tylko teren znajdujący się na zachód od założenia zamkowego (ryc. 4). Obszar ten dotąd nie był rozpoznany, a swoją uwagę przykuł charakterystycznym ukształtowaniem, identycznym jak forma terenowa, na której wznosi się zamek wysoki. Ta przesłanka skłoniła do sformułowania hipotezy, że mogło tam znajdować się drugie, zachodnie przedzamcze. O takiej możliwości pisał już B. Wasik w jednym z artykułów (Wasik 2015, s. 99). Na wspomnianym obszarze wcześniej znajdowała się zabudowa folwarczna, a obecnie mieszczą się budynki

${ }^{2}$ Projekt badawczy (nr 2bH 150078 83) finansowany w ramach Narodowego Programu Rozwoju Humanistyki. 
związane z lokalną przedsiębiorczością. Cześć z nich została wzniesiona na przełomie XIX i XX wieku. Niestety, ich forma i dodatkowe konstrukcje z nimi związane wykluczyły możliwość przeprowadzenia na tym obszarze prospekcji geofizycznej.

Celem podjętych badań archeologicznych w Papowie Biskupim była weryfikacja wspomnianej hipotezy dotyczącej istnienia drugiego przedzamcza, które miało być zlokalizowane na zachód od domu konwentu. W związku z tym, w ramach prac terenowych ${ }^{3}$, zdecydowano się wytyczyć sześć wykopów badawczych. Niestety, również i w tym przypadku obszar umożliwiający eksplorację był ograniczony (ryc. 5).

Pierwszy z wykopów, o wymiarach 3,0 (oś wschód-zachód)×1,5 m (oś północ-południe), założono w północno-zachodniej części domniemanego przedzamcza, nieopodal obecnej bramy wjazdowej prowadzącej na teren przedsiębiorstwa (ryc. 6). Pod humusem oraz warstwą współczesną, na około 84,20 m n.p.m., odsłonięto bruk kamienny, który według relacji starszych mieszkańców Papowa Biskupiego był reliktem drogi z XIX/XX wieku, prowadzącej do jeziora. Pod nim stwierdzono warstwy związane z jego budową. Co ciekawe, zakłócały one nawarstwienia, których treść geologiczną stanowił brązowy piasek z ciemnobrunatnymi plamami (warstwa nr 6) oraz czarno-brunatny piasek gliniasty (warstwa nr 7). W warstwie nr 6 natrafiono na 17 fragmentów naczyń ceramicznych stalowoszarych oraz tłok pieczętny. Według analizy przeprowadzonej przez Marcina Hlebionka tłok datowany jest na drugą połowę XV wieku, a więc czasy kiedy zamek był już pod zwierzchnictwem polskich starostów (ryc. 7). Niestety, ze względu na stan zachowania przedmiotu nie udało się ustalić wizerunku umieszczonego na stemplu (Hlebionek 2020, s. 144-148). W warstwie nr 7 odkryto zbiór 139 fragmentów naczyń ceramicznych datowanych wstępnie w szerokich ramach od XIV do XV wieku, najliczniejszy na stanowisku. Materiał ceramiczny o podobnej metryce, w liczbie 74 sztuk, stwierdzono także w warstwie nr 10 (ciemnobrązowy piasek z małymi kamieniami). W trakcie eksploracji warstw 7 i 10 (na około 83,80-83,40 m n.p.m.), w południowozachodnim narożniku wykopu zarejestrowano również warstwę zawierającą fragmenty cegieł oraz pozostałości zaprawy (warstwa nr 9). Od około 83,50 m n.p.m. na powierzchni uwidocznił się czarny zbity piasek (warstwa nr 12), który wraz z postępującą eksploracją zaczął systematycznie rozpościerać się na całym dnie wykopu. Dodatkowo był on poprzedzony warstwą jasnego piasku (warstwa nr 13). Niestety, nie udało się osiągnąć spągu warstwy nr 12, ale można przyjąć, że stanowiła ona tzw. humus pierwotny z czasów krzyżackich. Eksplorację wykopu zakończono na około $82,30 \mathrm{~m}$ n.p.m. ze względu na wybijającą wodę, która uniemożliwiła dalsze prace (Cisło i in. 2018).

\footnotetext{
${ }^{3}$ Pracami kierowała Anna Roman.
} 


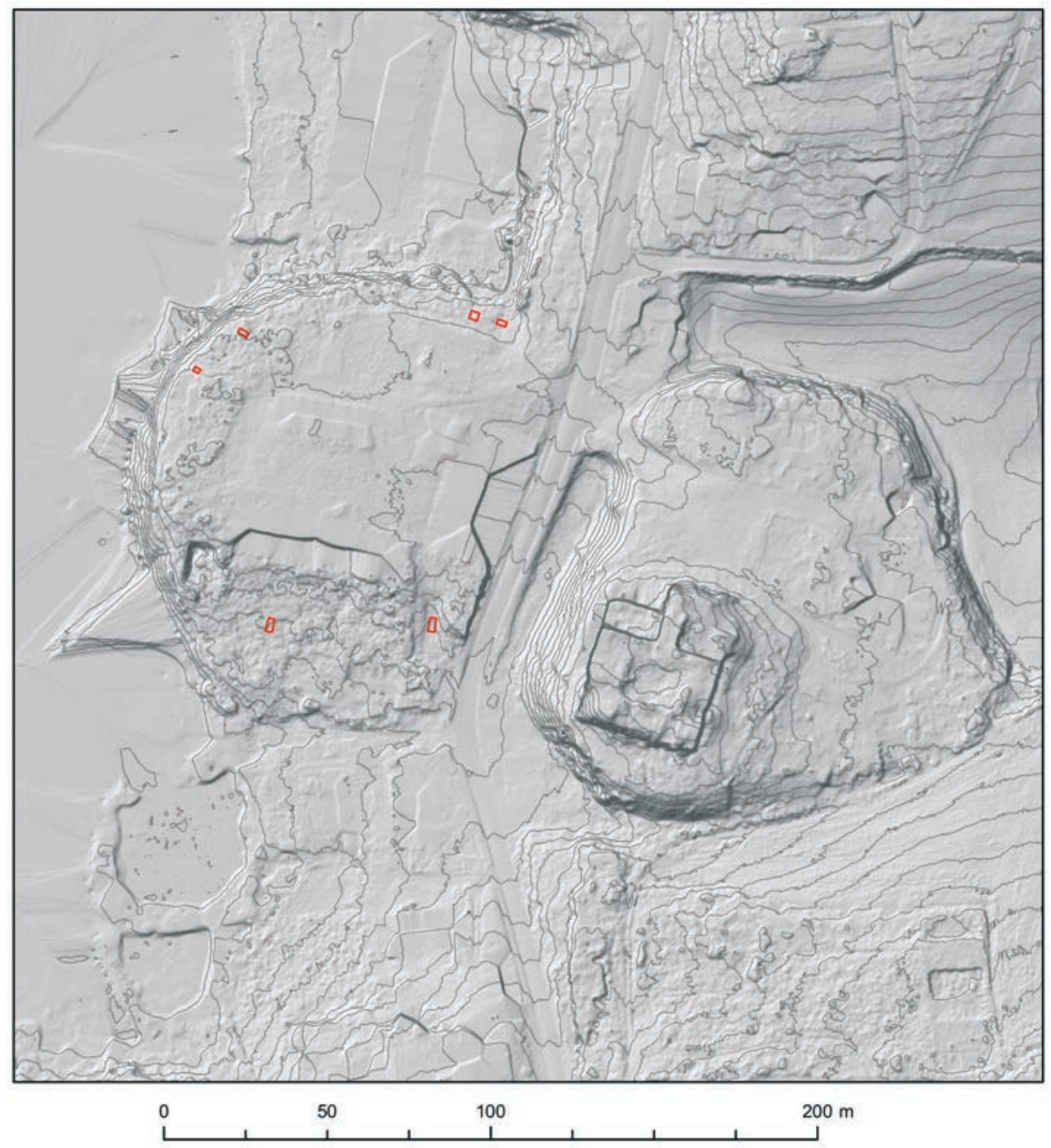

Ryc. 4. Papowo Biskupie, pow. Chełmno. Model terenu z uwzględnieniem obszaru z domem konwentu i przedzamczem wschodnim (wschodnia „wyspa”) oraz domniemanym przedzamczem zachodnim (zachodnia ,wyspa”) (oprac. S. Tyszkowski)

Fig. 4. Papowo Biskupie, Chełmno district. Terrain model taking into account the area with the monastery's house and the east castle's ward (eastern 'island') and the alleged west castle's ward (western 'island') (edited by S. Tyszkowski)

Na tej samej osi, $6 \mathrm{~m}$ na zachód, wytyczono wykop $\mathrm{nr} 4$ o wymiarach $2,5 \times 2,5 \mathrm{~m}$. Odkryta $\mathrm{w}$ tym miejscu stratygrafia miała podobny charakter, jak w wykopie nr 1. Pod humusem stwierdzono współczesne zasypisko, natomiast niżej odsłonięto bruk, który stanowił dalszą części drogi prowadzącej do jeziora (ryc. 8). Pod kamieniami znajdowała się żwirowa podsypka o grubości około $10 \mathrm{~cm}$, a pod nią, na całej powierzchni wykopu, szarozielono-ciemnobrązowa 


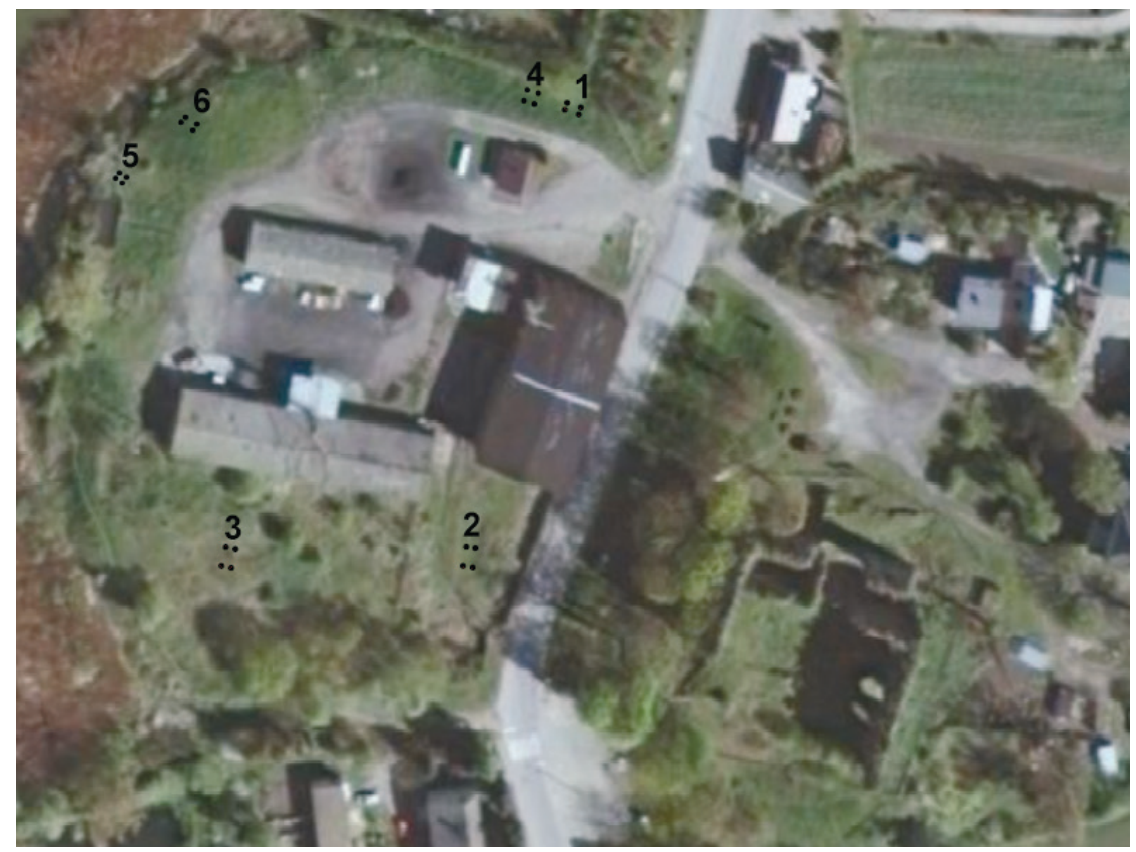

Ryc. 5. Papowo Biskupie, pow. Chełmno. Lokalizacja wykopów (oprac. S. Tyszkowski, R. Cisło)

Fig. 5. Papowo Biskupie, Chełmno district. Location of trenches (edited by S. Tyszkowski and R. Cisło)

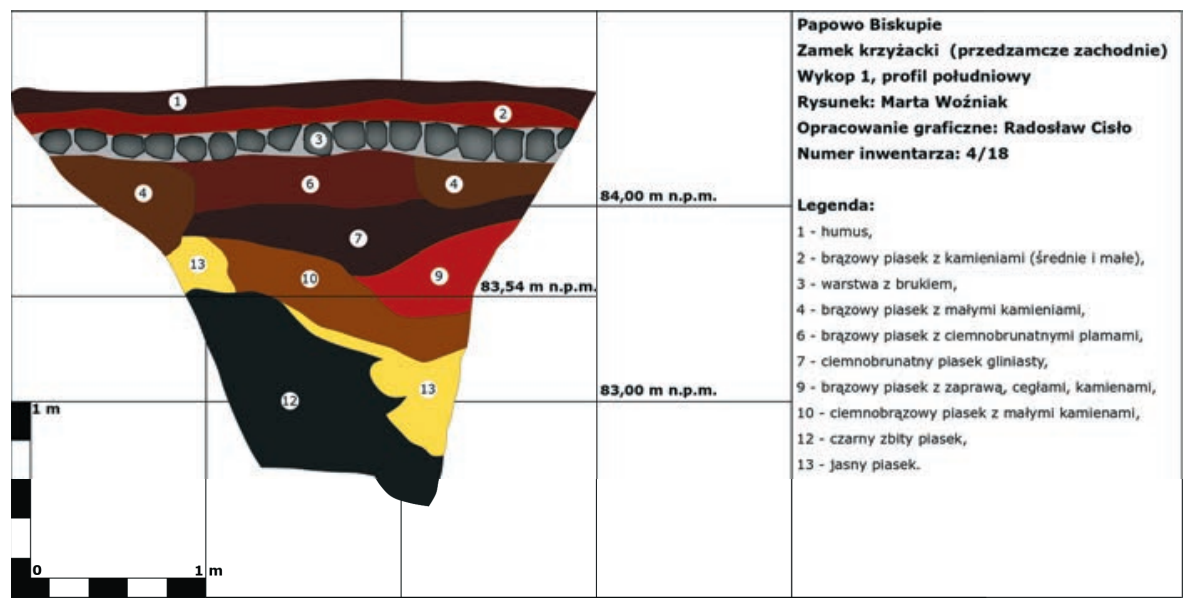

Ryc. 6. Papowo Biskupie, pow. Chełmno. Profil południowy wykopu nr 1 (rys. M. Woźniak, oprac. R. Cisło)

Fig. 6. Papowo Biskupie, Chełmno district. South section of trench no. 1 (drawing by M. Woźniak, edited by R. Cisło) 


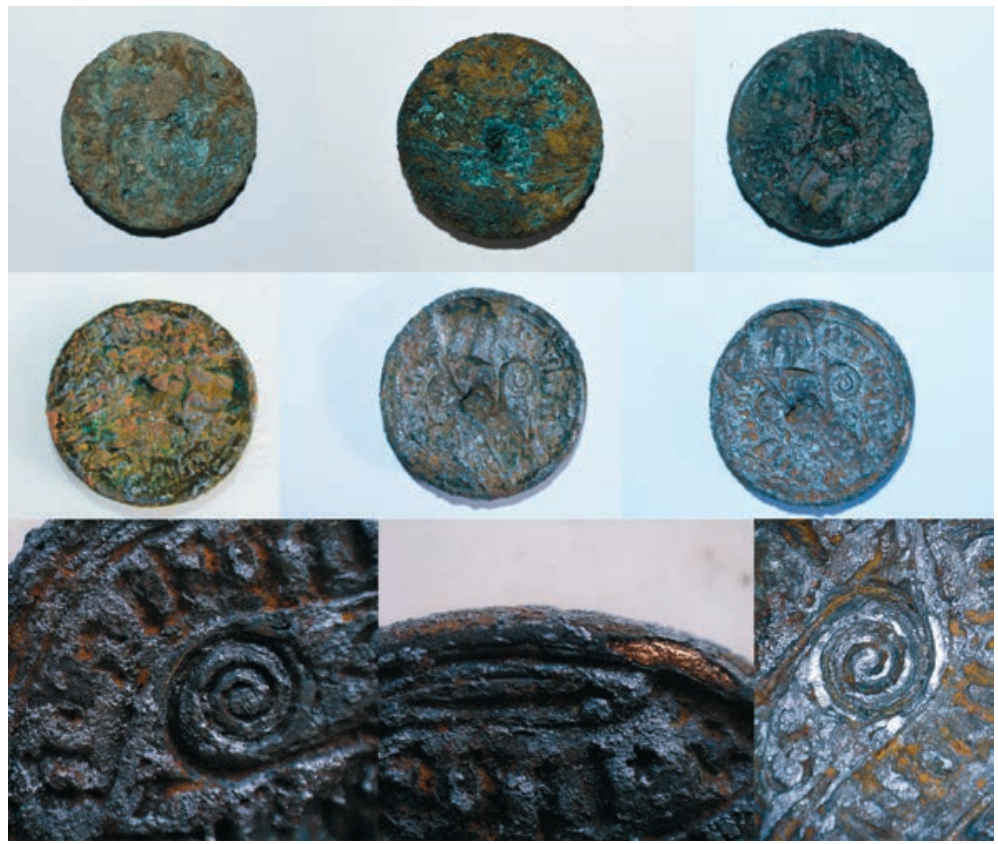

Ryc. 7. Papowo Biskupie, pow. Chełmno. Tłok pieczętny po kolejnych etapach konserwacji (fot. M. Nowak)

Fig. 7. Papowo Biskupie, Chełmno district. Seal matrix after subsequent stages of conservation (photo by M. Nowak)

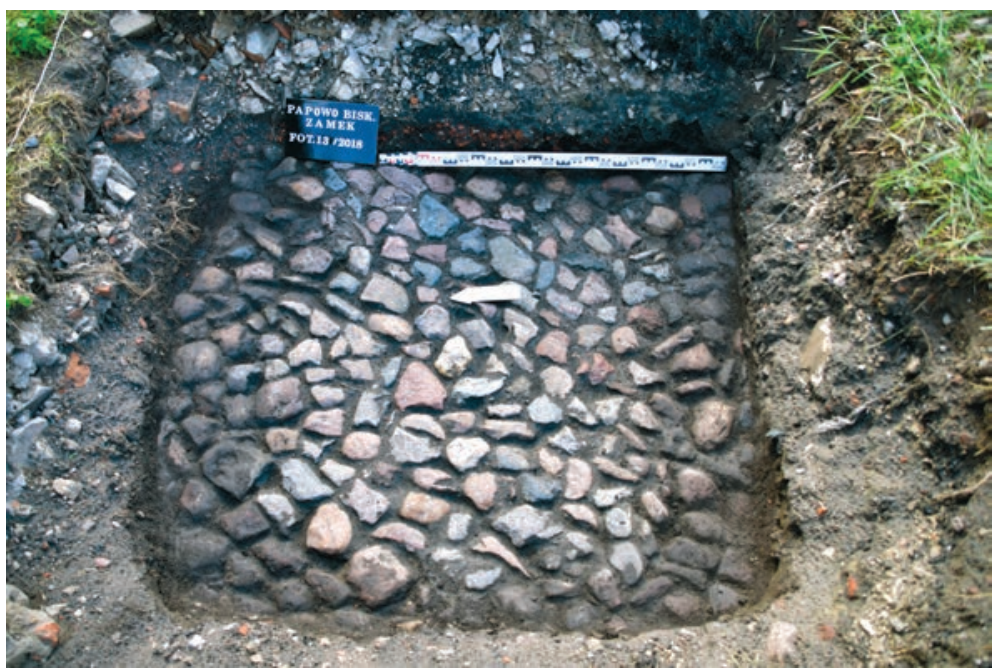

Ryc. 8. Papowo Biskupie, pow. Chełmno. Bruk kamienny z przełomu XIX i XX wieku (fot. A. Roman)

Fig. 8. Papowo Biskupie, Chelmno district. Stone pavement from the turn of the $19^{\text {th }}$ and $20^{\text {th }}$ centuries (photo by A. Roman) 
glina z rdzawymi i żółtymi wtrętami (warstwa nr 5), w której natrafiono na 13 fragmentów naczyń stalowoszarych. Miąższość tej warstwy wynosiła około $30 \mathrm{~cm}$, a jej spąg stwierdzono na około 83,80 m n.p.m. (ryc. 9). Poniżej natrafiono na przemieszane warstwy gliniaste ze spalenizną i drewnem bez materiału źródłowego. Pod nimi zalegał czarny zbity piasek (warstwa nr 10), którego strop zarejestrowano poniżej $83,50 \mathrm{~m}$ n.p.m. Warstwa ta miała analogiczny charakter jak warstwa nr $12 \mathrm{z}$ wykopu $\mathrm{nr}$ 1. Również i w tym przypadku nie osiągnięto spągu, a eksplorację przerwano na około $82,90 \mathrm{~m}$ n.p.m. z powodu wybijającej wody (Cisło i in. 2018).

Podczas badań w 2018 roku prowadzono także rozpoznanie południowo-wschodniej części domniemanego przedzamcza. Nieopodal budynku, usytuowanego równolegle do ulicy i bramy wjazdowej z przełomu XIX i XX wieku, wytyczono wykop $\mathrm{nr}$ 2, o wymiarach $2 \mathrm{~m}$ (oś zachód-wschód) na 4 m (oś północ-południe). W trakcie ściągania darni natrafiono na współczesny bruk, który był pozostałością nieczynnej drogi wjazdowej. Dodatkowo około 82,90 m n.p.m. zaczął uczytelniać się wkop związany z rurą kanalizacyjną, który przecinał horyzontalną stratygrafię wykopu, najlepiej czytelną na profilach zachodnim oraz północnym. Pod humusem uwidoczniły się jasne warstwy gliniaste ze znikomym i przemieszanym materiałem źródłowym. Ich łączna miąższość wynosiła 30-40 cm, a spąg znajdował się 82,40-82,30 m n.p.m. Bezpośrednio pod nimi zalegała brunatna glina (warstwa nr 10), która zajmowała praktycznie całą powierzchnię wykopu, z wyjątkiem wkopu związanego z rurą kanalizacyjną. Znaleziono w niej 43 fragmenty naczyń stalowoszarych, co stanowiło kolejny pod względem liczby, jednolity zbiór na stanowisku. Miąższość warstwy wynosiła około $55 \mathrm{~cm}$, a jej spąg stwierdzono na 82,10-81,90 m n.p.m. Niżej zalegały kolejne horyzontalnie układające się warstwy gliniaste, jednak zawierały nieliczny materiał źródłowy. Pod nimi, na około 81,50 m n.p.m., stwierdzono czarną glinę (warstwa nr 14), w której natrafiono na jeden fragment naczynia ceramicznego, kościane szydło i pozostałości drewna (ryc. 10). Warstwa ta miała podobny charakter jak warstwa nr $12 \mathrm{z}$ wykopu nr 1 oraz warstwa nr $10 \mathrm{z}$ wykopu $\mathrm{nr} 4$ (ryc. 11). Z powodu wybijającej wody eksplorację zdecydowano się zakończyć na około 81,40 m n.p.m. Dodatkowo wykonano serię odwiertów, w których nie stwierdzono spągu warstwy nr 14 (Cisło i in. 2018).

Kilkadziesiąt metrów na zachód od wykopu nr 2 wytyczono kolejny (wykop nr 3) o wymiarach $4 \times 2 \mathrm{~m}$. W początkowym etapie eksploracji natrafiono w nim na nawarstwienia współczesne oraz bruk z przełomu XIX i XX wieku. Bezpośrednio pod nim stwierdzono ciemnobrunatną glinę z wtrętami zaprawy, drobnymi kamieniami, fragmentami cegieł i spalenizną (warstwa nr 4), początkowo rozciągającej się na całej powierzchni wykopu, później zaznaczającej się jako regularny wkop, być może związany z zabudową. W warstwie tej zarejestrowano nieliczne fragmenty wczesnośredniowiecznych (2 szt.) i stalowoszarych (5 szt.) naczyń ceramicznych, przedmioty metalowe i kości zwierzęce. 


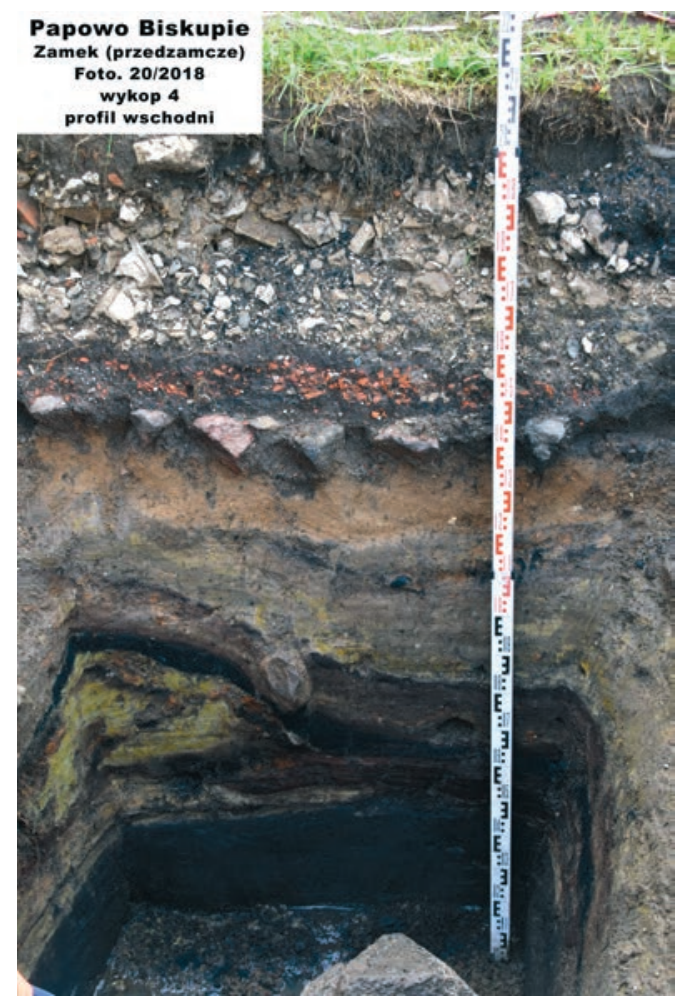

Ryc. 9. Papowo Biskupie, pow. Chełmno. Profil wschodni wykopu nr 4 (fot. A. Roman)

Fig. 9. Papowo Biskupie, Chełmno district. East section of trench no. 4 (photo by A. Roman)

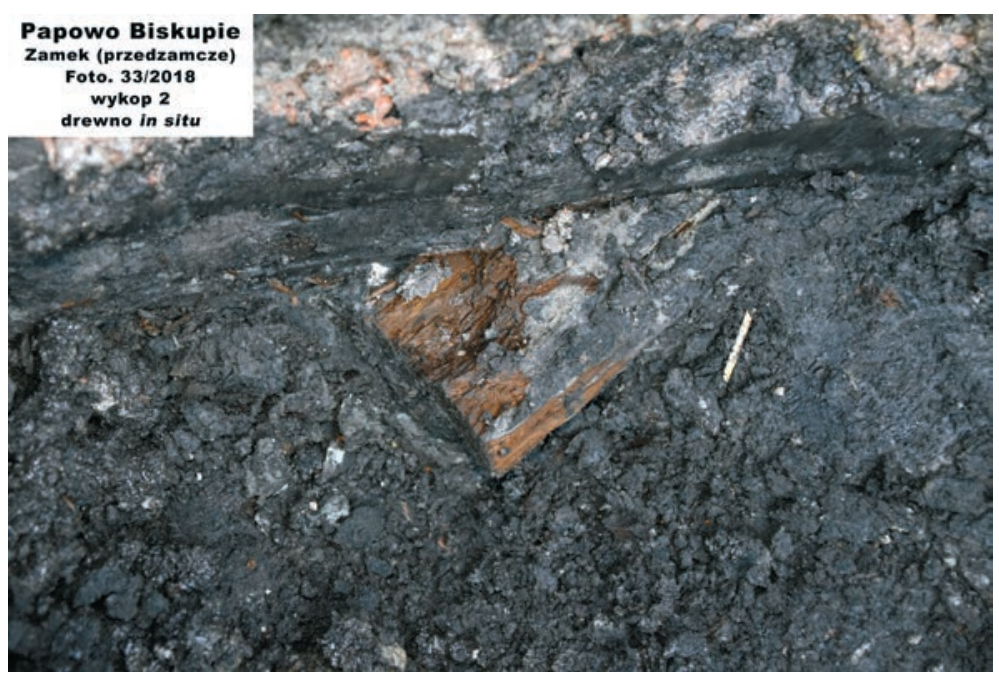

Ryc. 10. Papowo Biskupie, pow. Chełmno. Jeden z fragmentów drewna z warstwy nr 14 wykopu nr 2 (fot. R. Cisło)

Fig. 10. Papowo Biskupie, Chełmno district. One of wood fragments from layer 14 of trench no. 2 (photo by R. Cisło) 
Wkop przecinał warstwy jasnych glin z wtrętami zaprawy i cegieł oraz spalenizny bez jakichkolwiek artefaktów. Pod wspomnianymi nawarstwieniami, na poziomie $81,83-81,36 \mathrm{~m}$ n.p.m., zalegała żółta glina z miedzianymi wtrętami (warstwa nr 5), którą po dokonaniu odwiertu zinterpretowano jako calec (ryc. 12, 13) (Cisło i in. 2018).

Dwa kolejne wykopy założono w najbardziej na zachód wysuniętej części terenu domniemanego przedzamcza (ryc. 14). Pierwszy z nich (wykop nr 5), o wymiarach $1,90 \times 1,50 \mathrm{~m}$, wytyczono nieopodal budynku i nadjeziornej skarpy. Niestety, już w początkowej fazie eksploracji okazało się, że znajduje się on w miejscu przebiegu instalacji podłączonych do pobliskiego budynku. Pod humusem stwierdzono ciemnobrunatną glinę z kamieniami i śladami spalenizny (warstwa nr 3), którą można interpretować jako wkop związany ze wspomnianą instalacją. Poniżej zalegała zbita, żółto-zielona glina z wtrętami zaprawy, fragmentami cegieł oraz spalenizny (warstwa $\mathrm{nr}$ 2). Zawierała fragmenty przedmiotów metalowych i szklanych oraz kości zwierzęce, nie natrafiono natomiast na materiał ceramiczny. Dodatkowo miała ona nieregularny charaktery, a jej największa miąższość wynosiła około $60 \mathrm{~cm}$ przy profilu południowym $(84,40-$ 83,76 m n.p.m.). Niżej stwierdzono żółtą glinę z miedzianymi wtrętami (warstwa nr 4), która okazała się calcem. Jej maksymalną głębokość osiągnięto w odwiercie zakończonym na 82,27 m n.p.m. (Cisło i in. 2018).

Ostatni z wykopów - nr 6 - wytyczono na północ od wykopu nr 5 również nieopodal nadjeziornej skarpy. Pod humusem natrafiono na gliniaste oraz piaszczyste warstwy z niewielką ilością gruzu, jednak bez materiału źródłowego; ich spąg znajdował się na około 83,90 m n.p.m. Poniżej stwierdzono żółto-brązowy, zbity piasek ze spalenizną (warstwa nr 8), zawierający 14 przemieszanych fragmentów wczesnośredniowiecznych i stalowoszarych naczyń ceramicznych oraz 265 kości zwierzęcych - dwa szkielety w układzie anatomicznym (ryc. 15). Jeden z nich, mniejszy i pokryty wapnem, należał do psa i zlokalizowany był przy profilu zachodnim, drugi, (większy, w dużej mierze niekompletny, znajdował się przy profilu północnym. Dodatkowo w południowo-zachodniej części wykopu wykonano odwiert, który wykazał, że spąg warstwy $\mathrm{nr} 8$ znajdował się na około 83,21 m n.p.m., natomiast niżej stwierdzono warstwę ciemnobrunatnej gliny (warstwa 9). Odwiert zakończono na poziomie około 81,11 m n.p.m. ze względu na wybijającą wodę (Cisło i in. 2018).

\section{PODSUMOWANIE}

Badania archeologiczne prowadzone w obrębie pozostałości zamku w Papowie Biskupim potwierdziły istnienie śladów osadnictwa na obszarze położonym na zachód od domu konwentu, co można łączyć z istnieniem w tym miejscu drugiego przedzamcza. Niestety, w toku prac nie natrafiono na żadne relikty 


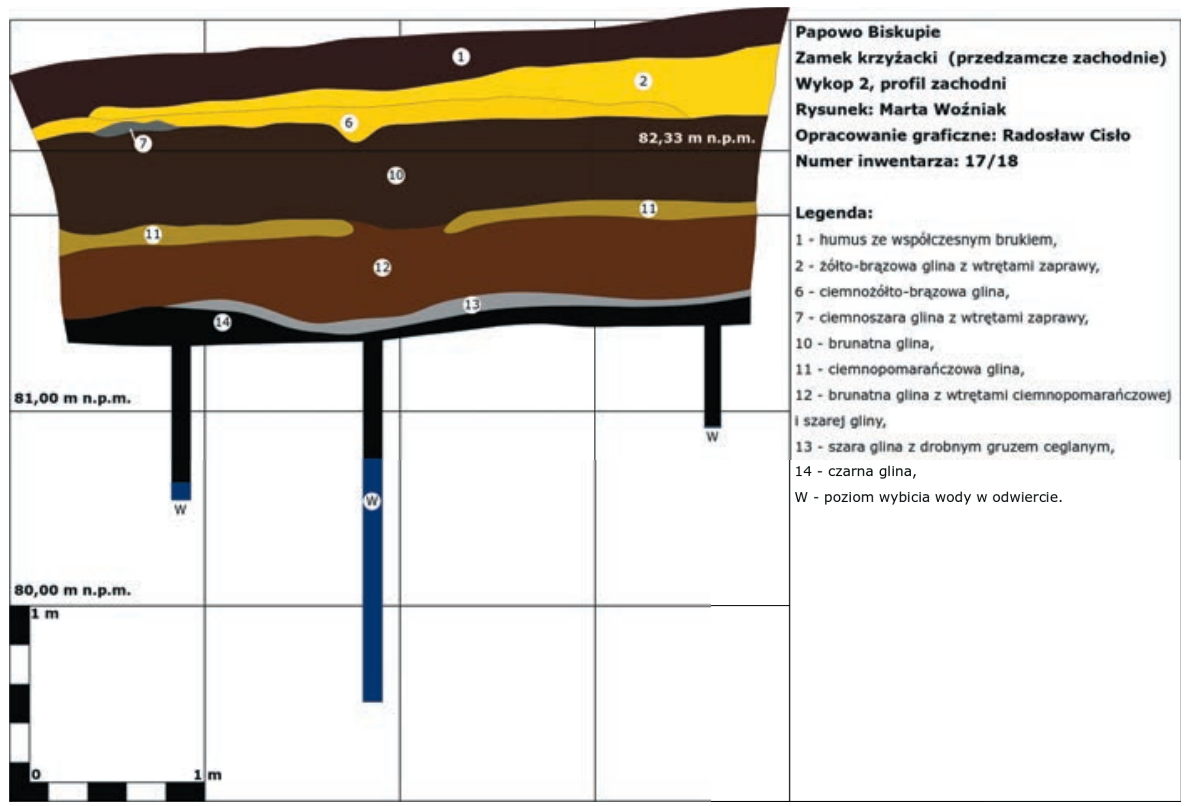

Ryc. 11. Papowo Biskupie, pow. Chełmno. Profil zachodni wykopu nr 2 (rys. M. Woźniak, oprac. R. Cisło)

Fig. 11. Papowo Biskupie, Chełmno district. West section of trench no. 2 (drawing by M. Woźniak, edited by R. Cisło)

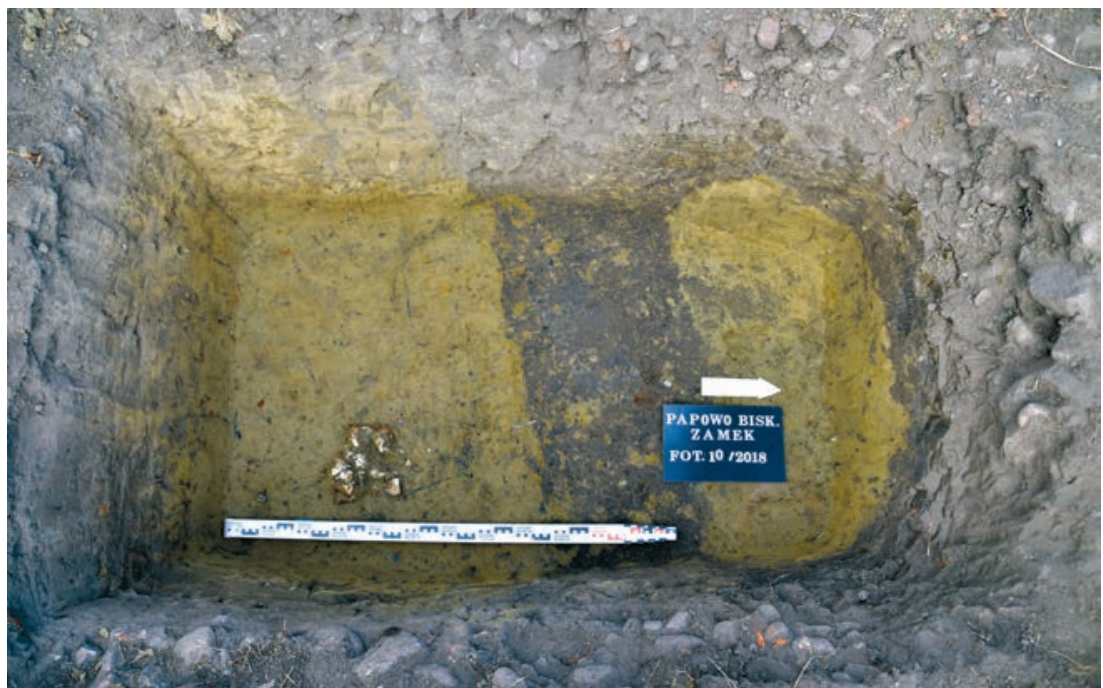

Ryc. 12. Papowo Biskupie, pow. Chełmno. Rzut dna wykopu nr 3 (fot. A. Roman)

Fig. 12. Papowo Biskupie, Chełmno district. Plan of the bottom of trench no. 3 (photo by A. Roman) 


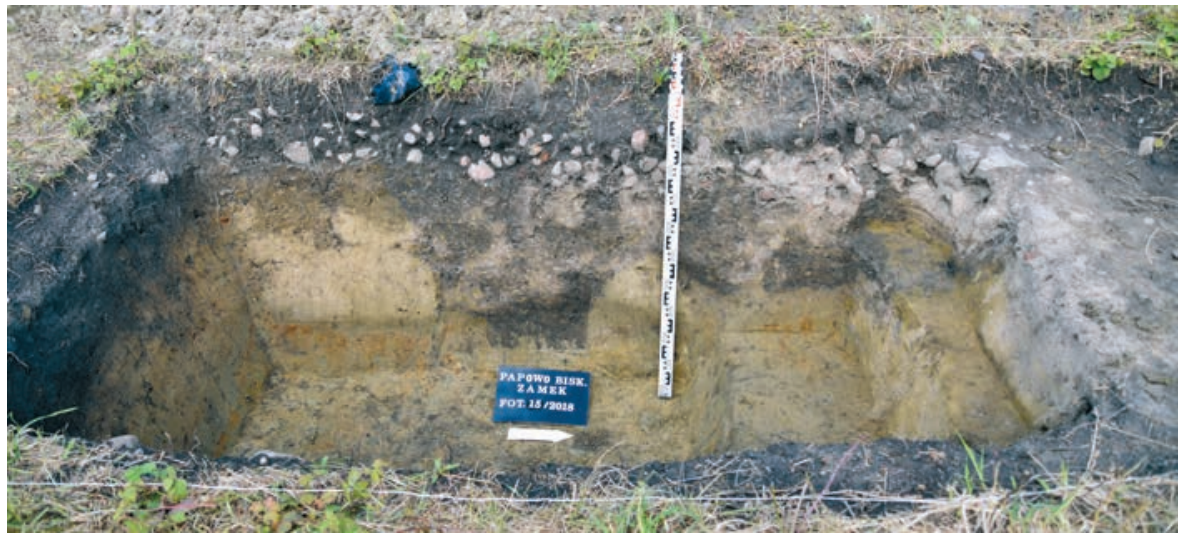

Ryc. 13. Papowo Biskupie, pow. Chełmno. Profil zachodni wykopu nr 5 (fot. A. Roman)

Fig. 13. Papowo Biskupie, Chełmno district. West section of trench no. 4 (photo by A. Roman)

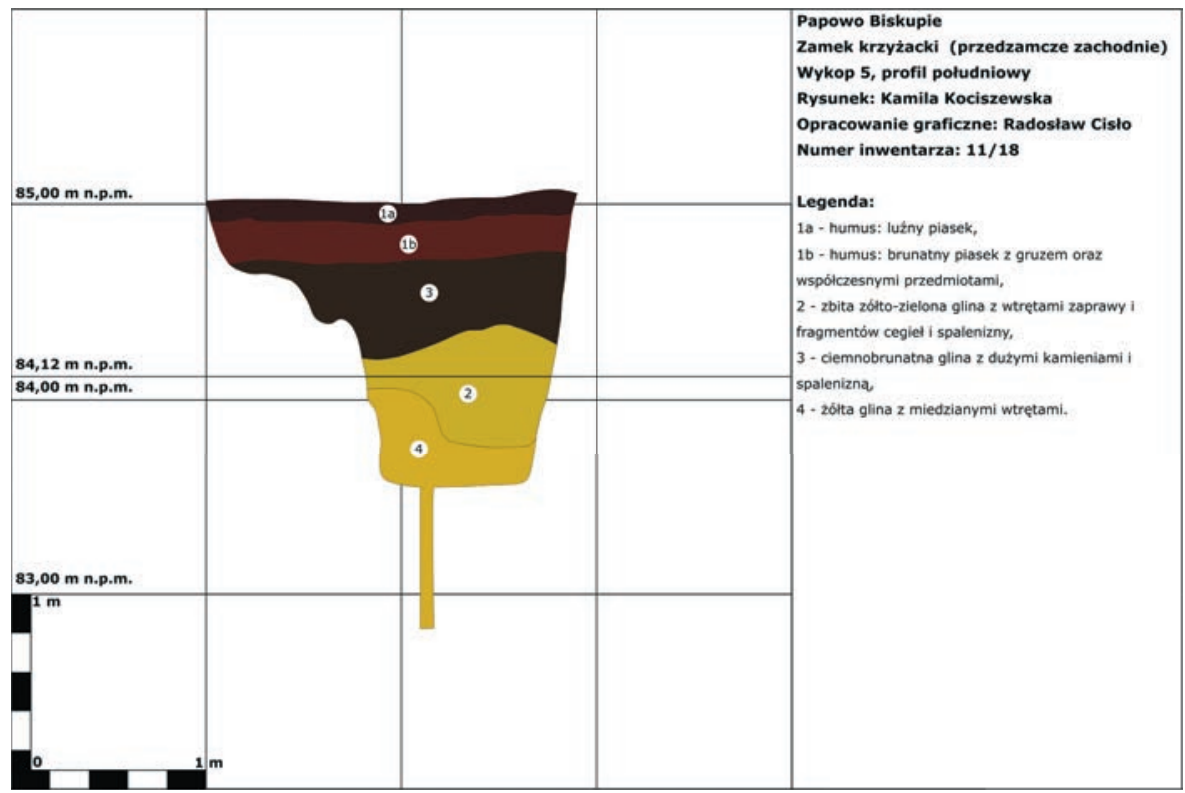

Ryc. 14. Papowo Biskupie, pow. Chełmno. Profil południowy wykopu nr 5 (rys. K. Kociszewska, oprac. R. Cisło)

Fig. 14. Papowo Biskupie, Chełmno district. South section of trench no. 5 (drawing by K. Kociszewska, edited by R. Cisło)

architektoniczne, dlatego też trudno wnioskować o charakterze zabudowy w tej części założenia zamkowego. Rozsądnym wydaje się jednak przyjąć hipotezę B. Wasika mówiącą, że budynki były wzniesione w konstrukcji drewnianej, zwłaszcza, że w nawarstwieniach średniowiecznych (wykopy nr 2 i 4) natrafiono 


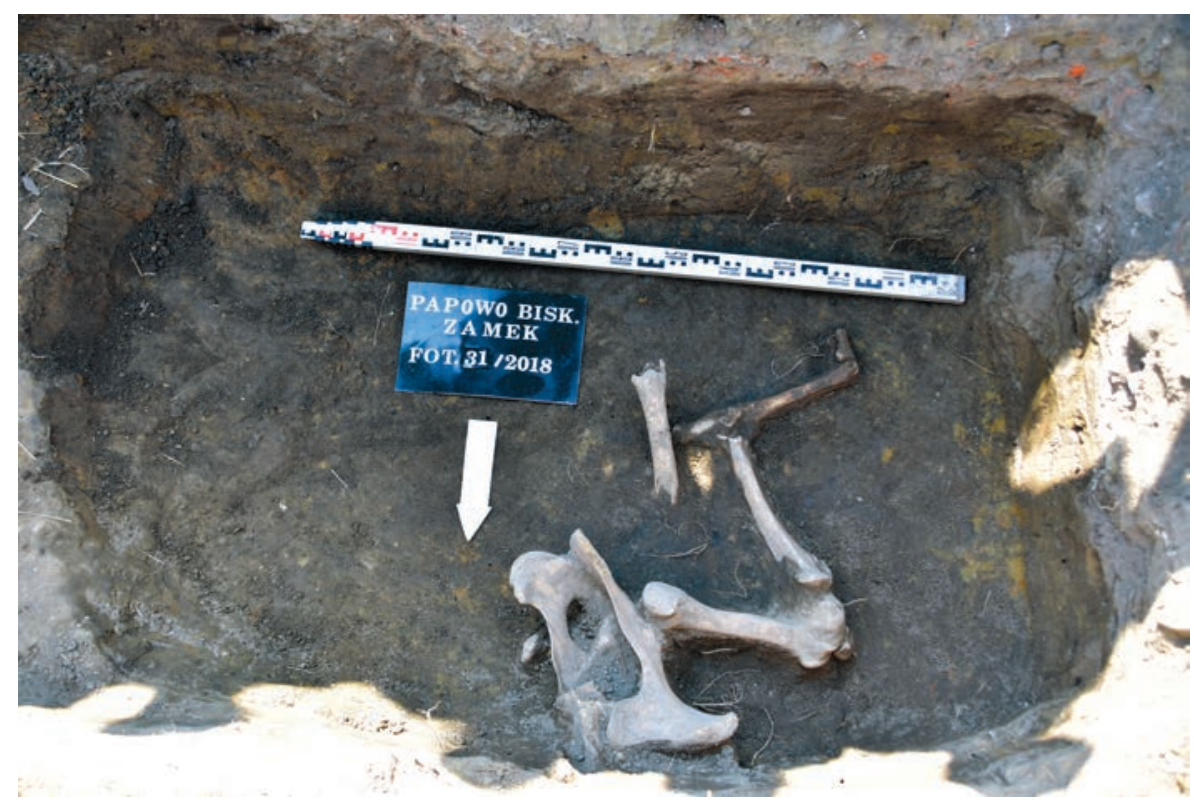

Ryc. 15. Papowo Biskupie, pow. Chełmno. Szkielet zwierzęcy odkryty w wykopie nr 6 (fot. A. Roman)

Fig. 15. Papowo Biskupie, Chełmno district. Animal skeleton discovered in trench no. 6 (photo by A. Roman)

na pozostałości drewna (Wasik 2015, s. 99). Istotnym faktem jest również bardzo dobre udokumentowanie późnośredniowiecznych poziomów osadniczych, przede wszystkim w wykopach nr 1 i 2, datowanych na XIV-XV wiek, które mogą mieć związek ze znaczącą rangą zamku w Papowie w czasach krzyżackich. Oprócz tego na szczególną uwagę zasługuje unikatowe znalezisko tłoku pieczętnego, związanego z czasami gdy władzę nad warownią sprawowali polscy starostowie.

\section{Bibliografia}

Arszyński M., 1958, Ruiny zamku w Papowie Biskupim, pow. Chełmno, woj. bydgoskie - dokumentacja historyczna do prac konserwatorskich, maszynopis w archiwum Wojewódzkiego Urzędu Ochrony Zabytków w Toruniu, Toruń.

Cisło R., Roman A., Stawarz N., Woźniak M., 2018, Sprawozdanie z badań archeologiczno-architektonicznych w Papowie Biskupim, maszynopis w archiwum Wojewódzkiego Urzędu Ochrony Zabytków w Toruniu, Toruń.

Clasen K.H., 1927, Die mittelalteriche Kunst im Gebiete des Deutschordensstaates Preussen, t. 1: Die Burgbauten, Königsberg. 
Guerquin B., 1984, Zamki w Polsce, Warszawa.

Heise J., 1889, Die Bau- und Kunstdenkmaler der Provinz Westpreussen: Des Kreis Thorn, z. 6-7, Danzig.

Herrmann C., 2007, Mittelalter Architektur im Preussenland. Untersuchungen zur Frage der Kunstlandschaft und geographie, Petersberg-Olsztyn.

Hlebionek M., 2020, Piętnastowieczny tłok pieczęci rycerskiej z zamku w Papowie Biskupim, [w:] Castra Terrae Culmensis. Na rubieży chrześcijańskiego świata, t. 2, red. M. Wiewióra, Toruń, s. 144-148.

Jóźwiak S., 1997, Powstanie i rozwój struktury administracyjno-terytorialnej zakonu krzyżackiego na Kujawach i w ziemi chetmińskiej w latach 1246-1343, Toruń.

Kajzer L., Kołodziejski S., Salm J. 2001, Leksykon zamków w Polsce, Warszawa.

Momot A., Wasik B., 2012, Sprawozdanie z badań archeologiczno-architektonicznych zamku w Papowie Biskupim w 2012 roku, maszynopis w archiwum Wojewódzkiego Konserwatora Zabytków w Toruniu oraz w Instytucie Archeologii UMK, Toruń.

Momot A., Wasik B., 2015, Zamek w Papowie Biskupim na ziemi chetmińskiej $w$ świetle najnowszych badań, [w:] XIX Sesja Pomorzoznawcza, red. A. Jankowski i in., Acta Archeologica Pomoranica 5, Szczecin, s. 317-329.

Momot A., Wasik B., Wiewióra M., 2014, Zamek krzyżacki w Papowie Biskupim. Nowe odkrycia i nowe interpretacje, Rocznik Grudziądzki, t. 22, s. 65-98.

Rozynkowski W., 1995, Średniowieczne dzieje Papowa Biskupiego, Papowo Biskupie.

Rozynkowski W., 2002, Zamek krzyżacki w Papowie Biskupim - klasztor, warownia, ośrodek administracyjny i gospodarczy, [w:] Zamki i przestrzeń społeczna w Europie Środkowej $i$ Wschodniej, red. M. Antoniewicz, Warszawa, s. 339352.

Schmid B., 1939, Bau- und Kunstdenkmäler der Ordenszeit in Preussen, t. 1: Kulmerland und Pomerellen, Marienburg.

Schmid B., 1940, Die Burgen des deutschen Ritterordens in Preussen. Ergänzungsheft, Berlin.

Sławiński I., 1959, Opis techniczny do inwentaryzacji zamku krzyżackiego w Papowie Biskupim, pow. Chełmno, maszynopis w archiwum Wojewódzkiego Urzędu Ochrony Zabytków w Toruniu, Toruń.

Steinbrecht C., 1888, Die Baukunst des Deutschen Ritterordens in Preussen, t. 2: Preussen zur Zeit der Landmeister, Berlin.

Torbus T., 1998, Die Konventsburgen in Deutschordensland Preussen, München.

Wasik B., 2015, Dzieje budowy i architektura zamku w Papowie Biskupim na ziemi chetmińskiej ws świetle ostatnich badań, Biuletyn Historii Sztuki, R. 77, s. 83-101.

Wasik B., 2016, Budownictwo zamkowe na ziemi chetmińskiej (od XIII do XV wieku), Toruń. 
Wiewióra M., 2013, Studia nad średniowiecznym warsztatem budowlanym zamku krzyżackiego w Papowie Biskupim, Ochrona Zabytów, 66, nr 1-4(260-263), s. 181-200.

Wiewióra M., 2007, Badania archeologiczno-architektoniczne średniowiecznego zamku w Papowie Biskupim w ziemi chetmińskiej, Archeologia Historia Polona, t. 17 , s. 293-305.

\section{ARCHAEOLOGICAL VERIFICATION OF WEST CASTLE'S WARD OF TEUTONIC CASTLE IN PAPOWO BISKUPIE}

Keywords: Papowo Biskupie, castle, castle's ward, Teutonic Knights, Castra Terrae Culmensis, Chełmno Land.

\section{Summary}

The purpose of archaeological research in Papowo Biskupie was to verify the said hypothesis regarding the existence of a second castle ward, which was to be located on west of the convent's house. Archaeological research confirmed the existence of traces of settlement in the area located west of the convent's house, which can be combined with the existence of a second castle ward in this place. Unfortunately, no architectural relics were found in the course of the work, which is why it is difficult to conclude anything about the character of the building in this part of the castle's assumption. Probably the buildings were erected in a wooden construction. An important fact is also the very good documentation of late medieval settlement levels, dated to the XIV-XV century, which may be related to the significant rank of the castle in Papowo in the Teutonic era. 
